\title{
Postnatal development and control of the pulmonary surfactant system in the tammar wallaby Macropus eugenii
}

\author{
Natalie J. Miller, Sandra Orgeig*, Christopher B. Daniels and Russell V. Baudinette \\ Department of Environmental Biology, Adelaide University, Adelaide, SA 5005, Australia \\ *Author for correspondence (e-mail: sandra.orgeig@adelaide.edu.au)
}

Accepted 5 September 2001

\begin{abstract}
Summary
Marsupials are born at an early stage of development and are adapted for future development inside the pouch. Whether the pulmonary surfactant system is fully established at this altricial stage is unknown. This study correlates the presence of surfactant proteins (SP-A, SP-B and SP-D), using immunohistochemistry, with the $e x$ utero development of the lung in the tammar wallaby Macropus eugenii and also investigates the control of phosphatidylcholine (PC) secretion from developing alveolar type II cells. All three surfactant proteins were found at the site of gas exchange in the lungs of joeys at all ages, even at birth when the lungs are in the early stages of the terminal air-sac phase. Co-cultures of alveolar type II cells and fibroblasts were isolated from the lungs of 30- and 70-dayold joeys and incubated with the hormones dexamethasone $\left(10 \mu \mathrm{moll}^{-1}\right)$, prolactin $\left(1 \mu \mathrm{moll}^{-1}\right)$ or triiodothyronine $\left(100 \mu \mathrm{moll}^{-1}\right)$ or with the autonomic secretagogues

isoproterenol $\left(100 \mu \mathrm{moll}^{-1}\right)$ or carbamylcholine chloride $\left(100 \mu \mathrm{moll}^{-1}\right)$. Basal secretion of PC was greater at 30 days of age than at 70 days. Co-cultures responded to all five agonists at 30 days of age, but only the autonomic secretagogues caused a significant increase in PC secretion at 70 days of age. This demonstrates that, as the cells mature, their activity and responsiveness are reduced. The presence of the surfactant proteins at the site of gas exchange at birth suggests that the system is fully functional. It appears that surfactant development is coupled with the terminal air-sac phase of lung development rather than with birth, the length of gestation or the onset of air-breathing.

Key words: phosphatidylcholine, surfactant protein, dexamethasone, prolactin, triiodothyronine, isoproterenol, carbamylcholine chloride, lung, development, tammar wallaby, Macropus eugenii.
\end{abstract}

\section{Introduction}

Pulmonary surfactant is a complex mixture of lipids and proteins secreted by the alveolar type II (ATII) cells. It is stored in secretory vesicles termed lamellar bodies until it is released into the fluid lining the alveoli to lower and vary the surface tension with changes in alveolar surface area.

The development of the mammalian lung can be divided into five phases: embryonic, pseudoglandular, canalicular, terminal air-sac and alveolar (Runciman et al., 1996). The timing of lung development varies among species, but for most mammals the surfactant system appears to be fully functional by the terminal air-sac stage, which begins before birth (Burri, 1984; Sosenko and Frank, 1987). Marsupials are born at a very altricial stage after a short in-utero gestation and then complete their maturation in the pouch. Little is known about the development of the surfactant system in marsupials. When the tammar wallaby Macropus eugenii is born, its lungs are in the early stages of the terminal air-sac phase (Runciman et al., 1999). The ontogeny of the phospholipid class distribution in $M$. eugenii is comparable with that in eutherian mammals (Ribbons et al., 1989). However, for the surfactant system to be fully functional, the surfactant proteins are required. It is not known at which stage the proteins develop and how surfactant development is regulated in the tammar wallaby.

The lipid component of pulmonary surfactant consists of disaturated phospholipids (regarded as the active ingredient), unsaturated phospholipids and neutral lipids (predominantly cholesterol). The most abundant lipid is phosphatidylcholine (PC), which makes up approximately $80 \%$ of the total lipid fraction, and its main function is to reduce the surface tension at the air/liquid interface.

The four surfactant proteins so far described are surfactant protein-A (SP-A), SP-B, SP-C and SP-D. SP-A is a highly glycosylated, acidic and water-soluble protein that regulates the secretion and uptake of surfactant from the ATII cells (Massaro et al., 1982; Mettler et al., 1981). It also binds to phospholipids to modify their structure, surface properties and cellular metabolism. SP-A also plays a role in the immune response in the lung (Haagsman, 1998). SP-B is a hydrophobic peptide that functions to enhance the adsorption of the phospholipids to the air/liquid interface. SP-B also has significant surface-tension-lowering properties (Curstedt et al., 1987). SP-C is a hydrophobic peptide (Haagsman and Van 
Golde, 1991) that functions to enhance the adsorption of the phospholipids to the air/liquid interface, thereby improving the surface-active properties of lipid mixtures (Whitsett and Baatz, 1992). SP-D is a collagenous glycoprotein that, in conjunction with SP-A, functions in the immune response in the lung (Reid, 1998 ) and is also involved in the antioxidant system (Bridges et al., 2000).

Surfactant proteins have never been examined in marsupials. As the lung is relatively underdeveloped at birth (early terminal air-sac stage) and matures rapidly thereafter (Runciman et al., 1996), it is possible that the development of the surfactant proteins is not yet complete at birth. However, wallabies have pulmonary exchange at birth (R. V. Baudinette, unpublished observations), unlike some other marsupials, e.g. dunnarts, which rely upon gas exchange through the skin (Frappell and Mortola, 2000; Mortola et al., 1999).

The synthesis and secretion of pulmonary surfactant are controlled by various biochemical factors. Autonomic secretagogues are some of the most widely studied agonists of pulmonary surfactant. Adrenaline is the major stimulus for surfactant phospholipid secretion in mammals (Dobbs and Mason, 1979) and lizards (Wood et al., 1997), where it acts through $\beta$-adrenergic receptors on the ATII cells. Isolated ATII cells from eutherian mammals do not respond to cholinergic agonists (Brown and Longmore, 1981; Dobbs and Mason, 1979; Massaro et al., 1982; Miles et al., 1983; Robinson et al., 1984). It is likely that the stimulatory response to cholinergic agonists is restricted to heterothermic and ectothermic vertebrates because acetylcholine stimulates PC secretion from ATII cells isolated from lizards (Wood et al., 1999), frogs, lungfish and the heterothermic marsupial Sminthopsis crassicaudata (Wood et al., 2000). In these species, cholinergic stimulation may be particularly important during periods of low body temperature when the animals are conserving energy (Wood et al., 2000). Since M. eugenii is ectothermic for the initial period of development (up to 180 days of age), cholinergic agonists may elicit a response in the lung of the developing wallaby.

The effects of hormones on pulmonary surfactant secretion have been less widely studied. Whereas autonomic neurotransmitters are important surfactant secretagogues both during development and in adults, hormones appear to be particularly important during development. Glucocorticoids act through fibroblasts to induce cytodifferentiation of the ATII cells and stimulate synthesis and secretion of surfactant (Gonzales et al., 1990; Kresch and Gross, 1987; Perelman et al., 1985; Post and van Golde, 1988). Mice with mutated glucocorticoid receptor genes die shortly after birth as a result of respiratory failure, indicating the importance of glucocorticoids in lung development (Kellendonk et al., 1999). The adrenal cortex in marsupials is well developed at birth, so glucocorticoids may control surfactant secretion in co-cultures of ATII cells and fibroblasts from the developing tammar wallaby.

Thyroid hormones, including thyroxine $\left(\mathrm{T}_{4}\right)$ and triiodothyronine $\left(\mathrm{T}_{3}\right)$, stimulate the secretion of surfactant
(Ballard et al., 1984; Post and Smith, 1992). In the tammar wallaby, full thyroid maturity does not occur until the development of endothermy at approximately 180 days after birth (Janssens et al., 1990). Thyroid hormones also have limited access to the foetus through the placenta, so the mother does not contribute thyroid hormones to the foetus in sufficient amounts to meet foetal needs (Johnson and Everitt, 1995). This may suggest that thyroid hormones have no effect on PC secretion in the early stages of the developing tammar wallaby.

The role of the gonadotropic hormone prolactin in the regulation of surfactant homeostasis is controversial. Prolactin administration in vivo may trigger pulmonary surfactant synthesis (Hamosh and Hamosh, 1977) but does not appear to stimulate surfactant secretion (Van Petten and Bridges, 1979). Prolactin levels in the maternal plasma of the tammar wallaby are initially low, gradually increase to a peak at the first pouch exit (at 180-200 days after birth) and then rapidly decrease to a low level after the joey has permanently left the pouch (Hinds and Loudon, 1997). Since the joey can receive prolactin only through the milk, it may not have any effect on surfactant secretion in the very young tammar wallaby.

In this study, we examined the presence and location of the surfactant proteins SP-A, SP-B and SP-D in the tammar wallaby. Furthermore, we examined the control of surfactant secretion during development by analysing the effects of the hormones dexamethasone (DEX), triiodothyronine $\left(\mathrm{T}_{3}\right)$ and prolactin (PRL) and the autonomic secretagogues isoproterenol (ISOP) and carbamylcholine chloride (CARB) on PC secretion by type II cells co-cultured with fibroblasts.

\section{Materials and methods} Animals

Macropus eugenii Desmarest, 1817 joeys were removed from the teat of mothers held in a captive colony at the Waite campus, Adelaide University, South Australia. Wallabies were fed lucerne, hay and pellets, supplemented with carrots and eucalyptus leaves on occasion. Water was supplied ad libitum. Both male and female joeys were used in this study. Joeys were removed on the day of experimentation and transported to the North Terrace campus in a warm, humid container to mimic the pouch conditions and to reduce stress to the animals. In total, 23 joeys were used. One joey each at 0, 10, 30, 70, 120 and 180 days of age and one adult wallaby were used for determination of the presence and location of proteins. Eight joeys of 30 days of age and six joeys of 70 days of age were used for determination of the control of PC secretion from isolated cells. The age of the joeys was determined either by direct knowledge of birth date or by using head length scales (Murphy and Smith, 1970). Body mass and head length were measured at the start of each experiment. Body mass was $7.75 \pm 0.88 \mathrm{~g}$ for 30 -day-old joeys and $22.18 \pm 1.43 \mathrm{~g}$ for 70 -dayold joeys. Head length was $20.08 \pm 0.8 \mathrm{~mm}$ and $29.38 \pm 0.82 \mathrm{~mm}$ for 30- and 70-day-old joeys, respectively (values are means \pm S.E.M.). 
The surfactant system in Macropus eugenii 4033

\section{Transmission electron microscopy}

Tissue was prepared using the methods of Hayat (Hayat, 1970). The lungs were removed from the body cavity and fixed in $4 \%$ paraformaldehyde with $1.25 \%$ glutaraldehyde overnight. The tissue was then cut into small pieces (approximately $1 \mathrm{~mm}^{3}$ ) before being washed three times for 10 min each in phosphate-buffered saline (PBS) and post-fixed in $2 \%$ osmium tetroxide in PBS overnight at $4{ }^{\circ} \mathrm{C}$. The tissue was washed again three times for $10 \mathrm{~min}$ each in PBS before rapid dehydration in increasing concentrations of acetone (70\%, 90\%, $95 \%$ and $100 \%$; 4 min per concentration). The tissue was infiltrated with Araldite/Epon resin:acetone (1:1) overnight and then with $100 \%$ resin using three changes of $8 \mathrm{~h}$ each. The tissue was then embedded in fresh resin and polymerised at $60^{\circ} \mathrm{C}$ under vacuum overnight. Sections of $70 \mathrm{~nm}$ were cut and placed on 200 parallel mesh copper/palladium grids. The grids were stained with $5 \%$ uranyl acetate in $70 \%$ ethanol $(20 \mathrm{~min})$ and lead citrate $(20 \mathrm{~min})$ and examined under a Philips CM100 transmission electron microscope.

\section{Freeze substitution and immunohistochemistry}

The methods used for freeze substitution of lung tissue were similar to those used by Voorhout et al. (Voorhout et al., 1991a). The lungs were removed from the body cavity and placed in a fixative solution containing $2 \%$ paraformaldehyde, $0.5 \%$ glutaraldehyde and $0.1 \%$ dimethylsulphoxide in $0.1 \mathrm{moll}^{-1}$ PBS (pH7.4) for $4 \mathrm{~h}$. The tissue was then cryoprotected in $2 \mathrm{moll}^{-1}$ sucrose for $30 \mathrm{~min}$. If necessary, tissue was stored in cryoprotectant at $4{ }^{\circ} \mathrm{C}$ for a maximum of 1 month. Small pieces of tissue $\left(1 \mathrm{~mm}^{3}\right)$ were placed on metal stubs and held in place by a small drop of $2 \mathrm{moll}^{-1}$ sucrose solution. The tissue was then cryofixed by plunge-freezing in liquid nitrogen. Dehydration and embedding were performed in an Automatic freeze-substitution system (Leica Reichert, Austria). Dehydration of the tissue was achieved with methanol containing $0.5 \%$ uranyl acetate at $-90^{\circ} \mathrm{C}$ for at least $36 \mathrm{~h}$, with three solution changes during this time. The temperature was then increased to $-45^{\circ} \mathrm{C}$ at $5{ }^{\circ} \mathrm{Ch}^{-1}$, and the tissue was washed in pure methanol before resin-infiltration with Lowicryl HM20 resin. Infiltration was achieved with varying ratios of resin:methanol $(1: 1$ for $2 \mathrm{~h}, 2: 1$ for $2 \mathrm{~h}$ and pure resin for $2 \mathrm{~h}$ ) followed by infiltration in pure resin overnight. The tissue blocks were then polymerised with ultraviolet light for a minimum of 2 days. The tissue was cut into $70 \mathrm{~nm}$ sections, placed on 200 mesh nickel grids (coated with $2 \%$ collodion) and immediately processed for immunohistochemistry.

Immunogold labelling was performed on the grids using the methods of Sullivan et al. (Sullivan et al., 1998). Grids were placed on a drop of $20 \mathrm{mmoll}^{-1}$ glycine solution for $20 \mathrm{~min}$ to block any aldehyde groups. To prevent non-specific binding of antibodies, grids were washed for $15 \mathrm{~min}$ on droplets of $1 \%$ ovalbumin in PBS. Grids were then incubated overnight at $4{ }^{\circ} \mathrm{C}$ on $20 \mu \mathrm{l}$ droplets of primary antibody to the mature protein (rabbit anti-human SP-A, rabbit anti-bovine SP-B or rabbit anti-human SP-D) at a dilution of 1:50. Antibodies to SP-A and SP-B were kindly donated by Professor Jeffrey Whitsett (Children's Hospital Medical Center, Cincinnati, OH, USA). The antibody to SP-D was obtained commercially (Catalogue no. AB3434; Silenus Labs, Victoria, Australia). An antibody to mature SP-C was not available. Negative control grids were incubated with $1 \%$ ovalbumin in PBS instead of the primary antibody. Positive controls were achieved using mouse lung. After the incubation period, the grids were rinsed in droplets of PBS with $1 \%$ ovalbumin for six changes of 5 min each. The grids were then gold-labelled by placement on $20 \mu 1$ droplets of Protein-A/gold complex (diluted 1:100 in PBS) for $80 \mathrm{~min}$ and then rinsed in droplets of PBS for six changes of $5 \mathrm{~min}$ each. The gold complex was fixed to the tissue with a droplet of $2 \%$ glutaraldehyde for $5 \mathrm{~min}$, followed by washing in two droplets of PBS for $5 \mathrm{~min}$ each and four droplets of distilled water for $5 \mathrm{~min}$ each. The grids were then stained with $4 \%$ aqueous uranyl acetate $(35 \mathrm{~min})$ and lead citrate $(3 \mathrm{~min})$ and viewed using a Philips CT100 transmission electron microscope.

\section{Cell culture}

Aseptic techniques were used throughout the cell culture procedure and were performed in a laminar flowhood (model VWS-120, Clyde Industries, Australia). Animals were anaesthetized with an intraperitoneal injection of pentobarbitone sodium $\left(60 \mathrm{mg} \mathrm{ml}^{-1}\right.$ solution; Rhône Mérieux, Brisbane, Australia). The thorax was opened, and the lungs were perfused via the right ventricle with sterile saline $(0.9 \%$ $\mathrm{NaCl}$ ) containing heparin sodium (25000i.u. in $5 \mathrm{ml}$; David Bull Laboratories, Melbourne, Australia) until cleared of blood. The trachea was cannulated, and the lungs were lavaged with three volumes of sterile saline to remove intra-alveolar surfactant and macrophages. The lungs were removed, placed in 1-2 $\mathrm{ml}$ of DNAse (Worthington Biochemical Corporation, USA) and finely minced into $1 \mathrm{~mm}^{3}$ pieces. Tissue pieces were incubated in $0.1 \%$ trypsin and $0.02 \%$ EDTA at $37^{\circ} \mathrm{C}$ for $45 \mathrm{~min}$. Once dissociation was complete, the solution was filtered through a small mesh filter (Sigma Chemicals, Sydney, Australia). Enzymatic digestion was terminated immediately after filtering using $10 \%$ foetal bovine serum (FBS; Commonwealth Serum Laboratories, Adelaide, Australia). The filtered solution was centrifuged at $150 \mathrm{~g}$ for $8-10 \mathrm{~min}$ (Beckman GS-6R centrifuge, Beckman, Sydney, Australia).

To select type II cells and fibroblasts specifically, $60 \mathrm{~mm}$ bacteriological plastic dishes were coated with $3 \mathrm{ml}$ of bovine IgG (0.5 mg ml-1 ; Sigma Chemicals, Sydney, Australia) and allowed to incubate overnight at room temperature $\left(22^{\circ} \mathrm{C}\right)$. The plates were then washed with $2 \times \mathrm{PBS}$ and $1 \times$ Dulbecco's modified Eagles medium (DMEM; Sigma Chemicals). The cell pellet was resuspended in DMEM containing $0.1 \mathrm{mg} \mathrm{ml}^{-1}$ DNAse, and the suspension was poured onto the plates. The cells were incubated for $80 \mathrm{~min}$ at $37^{\circ} \mathrm{C}$ in a $10 \% \mathrm{CO}_{2}: 90 \%$ air incubator (Sanyo MCO-17A1 $\mathrm{CO}_{2}$ incubator; Sanyo Electrical Company, Japan). During this time, macrophages and other immune cells bind to the $\operatorname{IgG}$ molecules and adhere 


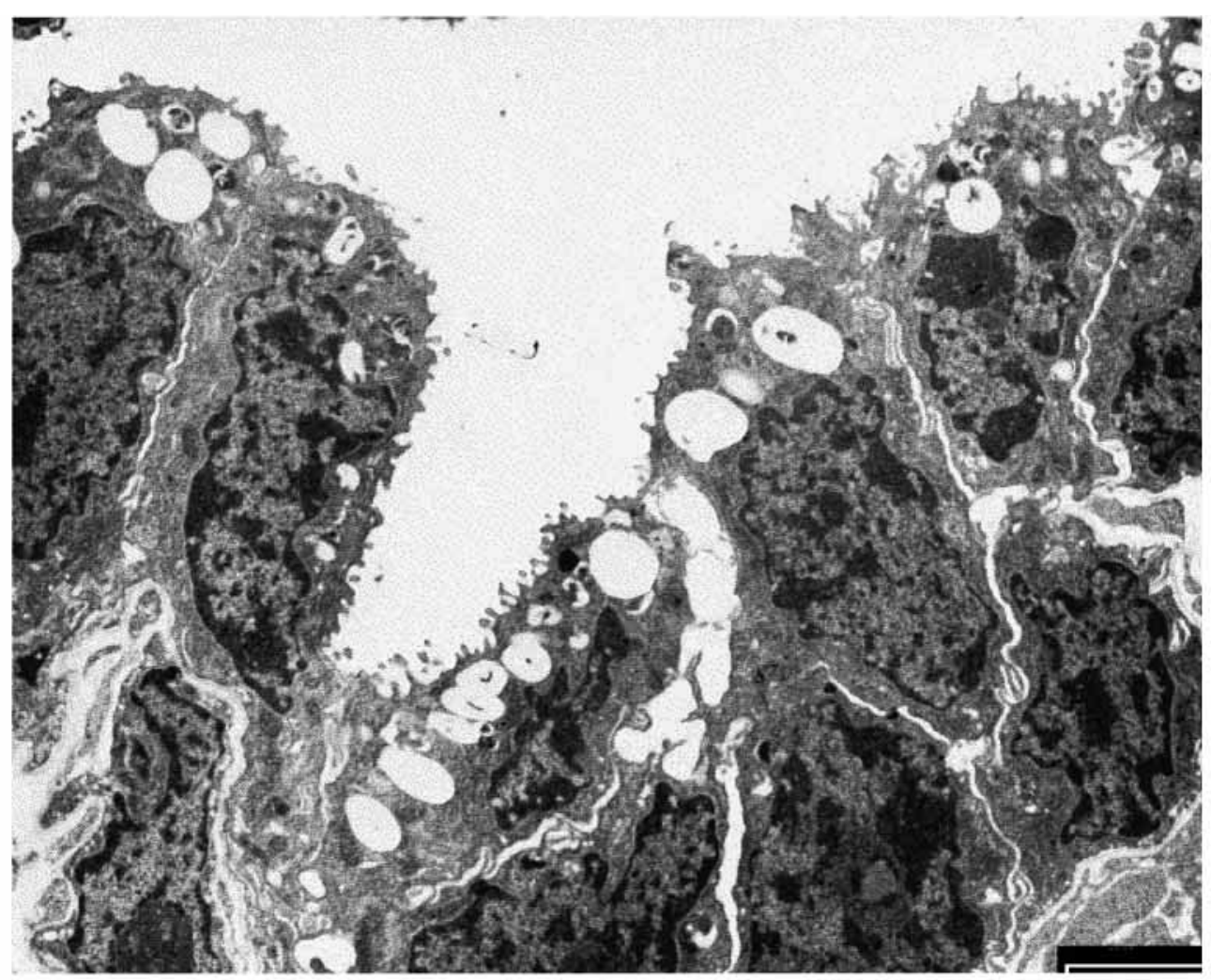

Fig. 1. Electron micrograph of alveolar type II cells lining the airspace in the lung tissue of Macropus eugenii at birth. Scale bar, $2 \mu \mathrm{m}$.

to the plates, allowing the remainder of the cells (the majority of which are type II cells and fibroblasts) to be poured off. The ratio of fibroblasts to ATII cells was determined using the Papanicolaou stain (Robinson et al., 1984).

Cell viability after isolation was measured by the exclusion of the vital dye Trypan Blue, and cells were counted using a haemocytometer (Neubauer improved, depth $0.1 \mathrm{~mm}$, $0.0025 \mathrm{~mm}^{2}$ ). The cell suspension was then diluted with DMEM containing $10 \%$ foetal calf serum (FCS) to a concentration of $3 \times 10^{6}$ cells ml ${ }^{-1}$. [ $\left.{ }^{3} \mathrm{H}\right]$ methylcholine chloride $\left(1 \mu \mathrm{ml}^{-1}\right.$; specific activity $3.00 \mathrm{TBq} \mathrm{mmol}^{-1}, 81.0 \mathrm{Ci} \mathrm{mmol}^{-1}$, $1 \mu \mathrm{Ci} \mathrm{ml}^{-1}$ ) was added to the cell suspension, and the cells were plated at 300000 cells per well in 96-well tissue culture plates on a layer of fibronectin:collagen $\left(1: 1 ; 5 \mu \mathrm{g}\right.$ protein $\mathrm{cm}^{-2}$; Boehringer Mannheim, Mannheim, Germany). The plated cells were then incubated overnight (or for a minimum of $20 \mathrm{~h}$ ) at $37^{\circ} \mathrm{C}$ in $10 \% \mathrm{CO}_{2}$.

As the majority of cells did not adhere following overnight incubation, the radiolabelled medium was removed very carefully from above the suspended cell layer immediately prior to the addition of the agonists, leaving more than $80 \%$ of the suspended cells in the well. Agonists were prepared immediately before use $\left(10 \mu \mathrm{moll}^{-1} \mathrm{DEX}, 1 \mu \mathrm{moll}^{-1} \mathrm{PRL}\right.$, $100 \mu \mathrm{moll}^{-1} \mathrm{~T}_{3}, 100 \mu \mathrm{moll}^{-1}$ ISOP, $100 \mu \mathrm{moll}^{-1} \mathrm{CARB}$; Sigma Chemicals). Each agonist $(100 \mu \mathrm{l})$ was added gently so as not to disrupt the cell suspension layer. For each preparation, four wells containing no agonists acted as controls. Cells were then incubated at $37^{\circ} \mathrm{C}$, in $10 \% \mathrm{CO}_{2}$, for $4 \mathrm{~h}$.
After incubation, the media and cells were separated and lipids extracted in chloroform:methanol (1:2) (Bligh and Dyer, 1959). Unlabelled phosphatidylcholine $(250 \mu \mathrm{l})$ from egg yolk $\left(250 \mu \mathrm{g} \mathrm{ml}^{-1}\right)$ was added to the media fractions to increase the recovery of radioactive lipids from the extractions. Lipids were reconstituted in $2 \mathrm{ml}$ of ReadyOrganic (Beckman, Sydney, Australia) liquid scintillation fluid and counted on a liquid scintillation analyser (Tricarb 2100TR, Canberra Packard, Melbourne, Australia), which was programmed to calculate direct disintegrations per minute (disints $\mathrm{min}^{-1}$ ).

\section{Cell viability}

To determine whether type II cells isolated from wallabies and cultured in suspension for $24 \mathrm{~h}$ are still capable of secreting surfactant proteins, we performed an SP-B enzyme-linked immunosorbent assay (ELISA) on the cell medium of selected cell populations of the different age groups, as described previously (Gregory et al., 1991). A fluorescent probe was used to determine the presence of lamellar bodies in type II cells after $24 \mathrm{~h}$ in culture. Cells were plated in a six-well plate and incubated overnight under the same conditions as mentioned above. LysoTracker Green DND-26 (50 $\mathrm{nmoll}^{-1}$; Molecular Probes, Eugene, OR, USA) was added to the cells and incubated for $90 \mathrm{~min}$ in the dark. Cells were then examined under an Olympus BX-51 microscope fitted with an Olympus BX-RFA reflected fluorescence system using an excitation filter, BP460-490, and a barrier filter, BA510IF. Cells were photographed with and without the fluorescence filter. In 
addition to the traditional dye-exclusion test of viability, cell viability after $24 \mathrm{~h}$ in culture was determined on selected samples using measurements of lactate dehydrogenase (LDH) with a cytotoxicity detection kit (Roche Diagnostics, Mannheim, Germany).

\section{Data analysis}

For each animal, a separate cell preparation was obtained. Each individual preparation yielded sufficient cells for four wells each per control and test group, and these were all plated on the same 96-well plate and incubated and treated identically. Control and test wells therefore differed only in the presence or type of agonist. Values of disintegrations $\mathrm{min}^{-1}$ were obtained for both the medium fraction and cell fraction from the liquid scintillation analyser. These values were used to calculate the percentage secretion of tritiated choline in the medium as a fraction of the total (medium plus cells). The values of agonist-stimulated secretion were then expressed as a percentage of basal secretion (i.e. control). All percentages were arcsine-transformed before an analysis of variance (ANOVA) was performed to test for significance. When significance was indicated, percentage basal secretion for each agonist was compared with the control values $(100 \%)$ using a paired $t$-test. Differences in agonist percentage basal secretion between age groups were compared using a Student's $t$-test. Significance was set at $P<0.05$, and all data are expressed as mean \pm S.E.M.

\section{Results \\ Transmission electron microscopy}

An electron micrograph of lung tissue from a joey at birth demonstrates ATII cells in situ (Fig. 1). The lung tissue and the cells of $M$. eugenii appear to be very fragile since the majority of the lamellar body contents have been removed, even when post-fixed with osmium tetroxide. They therefore appear as clear spaces. At birth, there are numerous ATII cells lining the airspaces. These cells have the classical appearance, with a large nucleus occupying the majority of the cytoplasm, lamellar bodies immediately beneath the apical surface and the apical membrane demonstrating numerous microvilli.

\section{Immunohistochemistry}

At birth, SP-A is present in the lamellar bodies and cytoplasm of the ATII cells and in the airspace (Fig. 2). The distribution of SP-A remained the same throughout development (data not shown). The presence of SP-B in the lung of M. eugenii can be seen in Fig. 3. At birth, SP-B is found in the cytoplasm and lamellar bodies of the ATII cells and in the airspaces. As with SP-A, the distribution of SP-B remained the same throughout development (data not shown). SP-D was found on the edges of the lamellar bodies of the ATII cells and in the cytoplasm surrounding them. It was also found in the airspace on the edges of the surfactant aggregates (Fig. 4). At 10 days of age, SP-D was found in the centre of the lamellar bodies and the surfactant aggregates. For the remainder of development, the distribution of SP-D remained constant (data
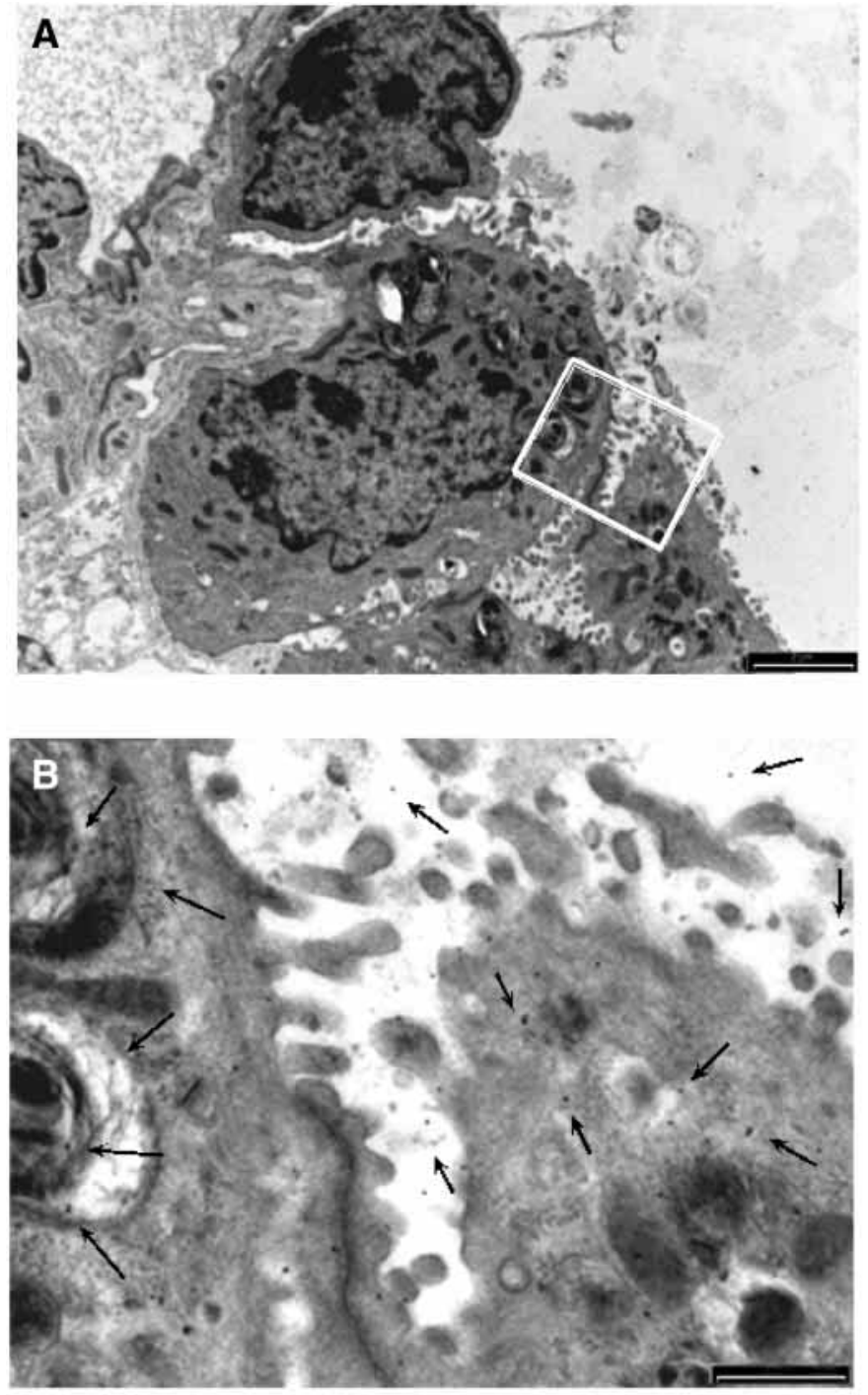

Fig. 2. (A) Low-magnification electron micrograph of lung tissue from Macropus eugenii at birth. Scale bar, $2 \mu \mathrm{m}$. (B) Enlargement of the region highlighted in A, showing the distribution of SP-A within the cytoplasm and airspace and associated with lamellar bodies. Immunogold particles are indicated by arrows. Scale bar, $0.5 \mu \mathrm{m}$.

not shown). There is a small amount of non-specific binding, as seen by isolated gold particles appearing in organelles such as the nucleus and mitochondria, and also by the gold particles appearing in the negative control grids (data not shown). However, the amount of non-specific binding is low, with the number of particles appearing on negative control grids representing less than $5 \%$ of the particles on test grids.

\section{Cell viability}

Cell counts and viability were obtained for each age group before secretion experiments commenced and are given as mean \pm S.E.M. For cells isolated from 30 -day-old animals, the cell count was $1.211 \times 10^{7} \pm 0.196 \times 10^{7}$ and the viability was $87.3 \pm 1.9 \%(N=8)$. For cells isolated from 70-day-old animals, the cell count was $2.722 \times 10^{7} \pm 0.519 \times 10^{7}$ and the viability was 


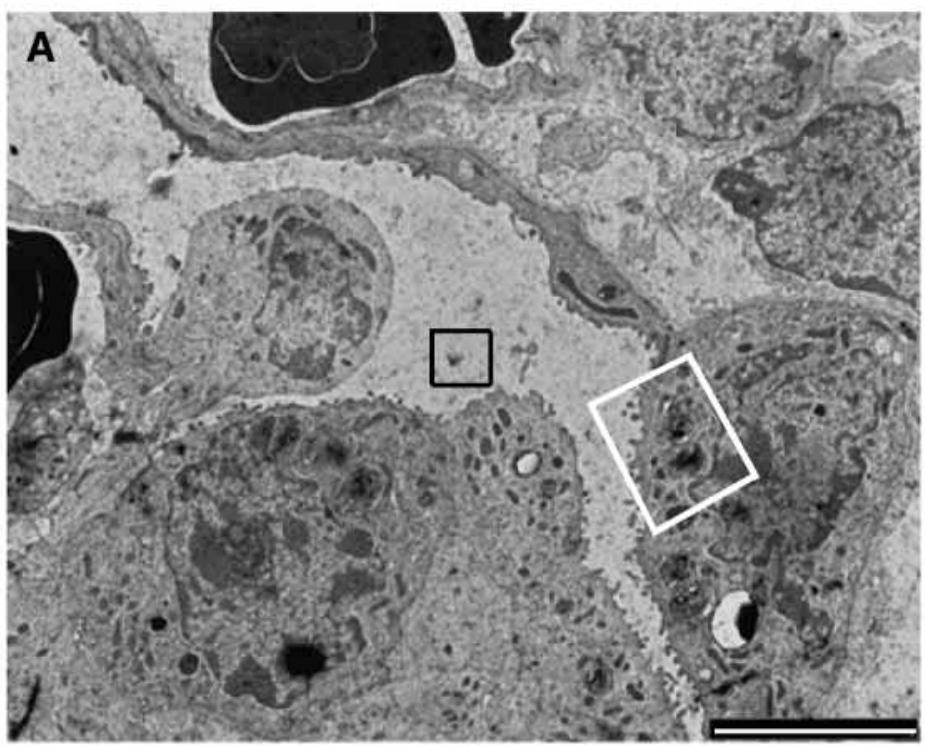

Fig. 3. (A) Low-magnification electron micrograph of lung tissue from Macropus eugenii at birth. Scale bar, $5 \mu \mathrm{m}$. (B) Enlargement of the airspace region highlighted in black in A, showing the distribution of SP-B associated with extracellular surfactant. Immunogold particles are indicated by arrows. Scale bar, $0.5 \mu \mathrm{m}$. (C) Enlargement of the cell region highlighted in white in A, showing the distribution of SP-B within the cytoplasm and lamellar bodies. Immunogold particles are indicated by arrows. Scale bar, $0.5 \mu \mathrm{m}$.
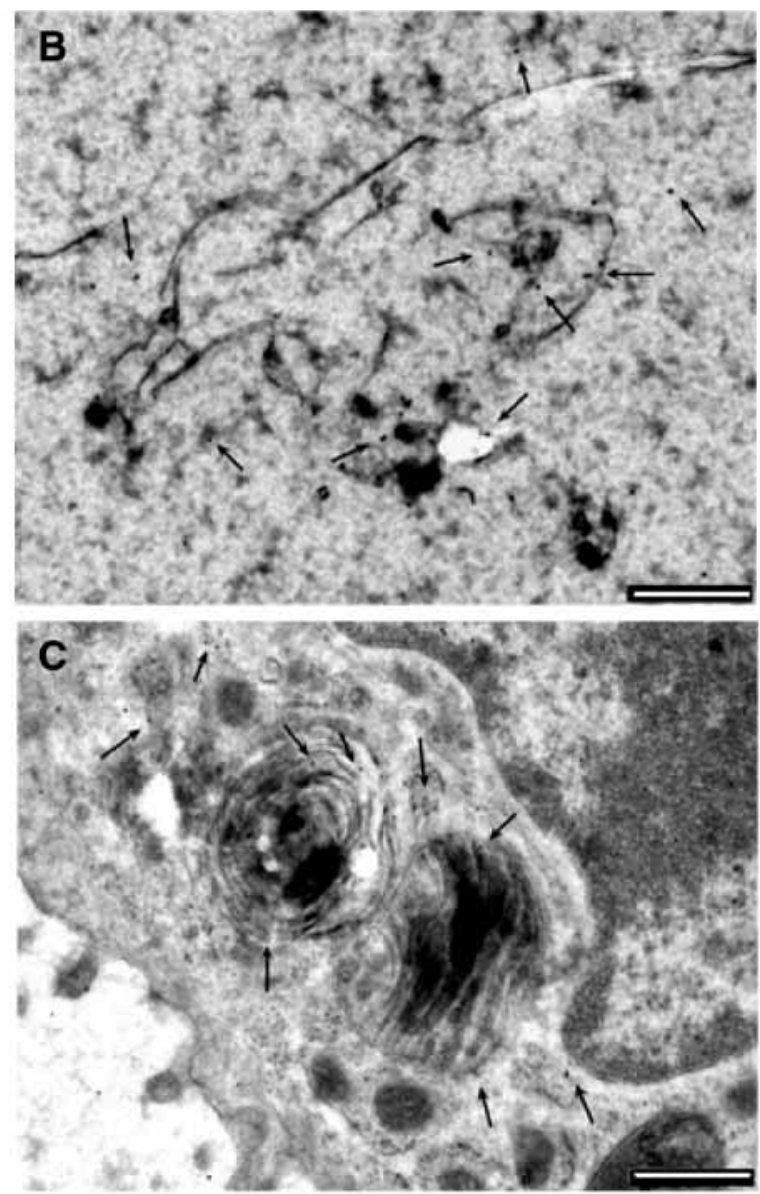

$93.2 \pm 0.9 \%(N=6)$. Cell viability after $24 \mathrm{~h}$ of incubation remained the same. Cell purity was high, with less than $10 \%$ contaminating cells (the majority being red and white blood cells), and the ATII cell:fibroblast ratio was approximately 1.4:1. After culture, the ATII cells still contained lamellar bodies (Fig. 5A,B) and were still able to secrete surfactant proteins. SPB content in the medium after culture was $2.566 \pm 0.896 \mu \mathrm{g} \mathrm{ml}^{-1}$. No LDH was detected in the medium from wells incubated for $24 \mathrm{~h}$, indicating that the cells remained viable throughout culture.

\section{Cell secretion experiments}

The basal secretion of PC at 30 days $(18.46 \pm 2.63 \%)$ was significantly higher than that at 70 days $(12.50 \pm 1.81 \%$; $P=0.05$ ) (Fig. 6). The effects of the hormones on PC secretion as a percentage of basal secretion are shown in Fig. 7. At 30 days, DEX caused a significant increase in secretion to $121.7 \pm 10.27 \% \quad(P=0.036)$, but it had no effect at 70 days $(101.17 \pm 5.38 ; \quad P=0.418)$. There was also a significant difference in the percentage of basal secretion in the presence of DEX between 30 and 70 days $(P=0.014)$ (Fig. 7A). PRL significantly increased PC secretion at 30 days to $144.47 \pm 20.56 \% \quad(P=0.041)$, but had no effect at 70 days $(109.32 \pm 10.67 \% ; \quad P=0.211)$. There was no significant difference in the percentage of basal secretion in the presence of PRL between 30 and 70 days $(P=0.080)$ (Fig. 7B).
$\mathrm{T}_{3}$ caused a significant increase in the amount of $\mathrm{PC}$ secreted at 30 days to $113.81 \pm 7.23 \%(P=0.05)$, but there was no significant change in PC secretion at 70 days $(87.82 \pm 6.10 \%$; $P=0.26$ ). There was also a significant difference in the percentage of basal secretion between 30 and 70 days $(P=0.013)$ (Fig. 7C).

ISOP caused a significant increase in PC secretion as a percentage of basal secretion at both 30 days $(128.01 \pm 6.99 \%$; $P=0.015)$ and 70 days $(109.32 \pm 8.03 \% ; P=0.028)$. There was also a significant difference in the percentage of basal secretion between 30 and 70 days $(P=0.041)$ (Fig. 8A). In response to $\mathrm{CARB}$, there was a significant increase at both 30 days $(147.24 \pm 13.15 \% ; P=0.004)$ and 70 days $(112.21 \pm 5.49 \%$; $P=0.038)$. There was also a significant difference in the percentage basal secretion between 30 and 70 days $(P=0.025)$ (Fig. 8B).

\section{Discussion}

\section{Transmission electron microscopy}

The appearance of the ATII cells in the wallaby is similar to that in other marsupials such as the fat-tailed dunnart Sminthopsis crassicaudata (Wood et al., 2000) and the bandicoot Isoodon macrourus (Gemmell, 1986), which in turn are virtually identical to the type II cells of all other vertebrates, ranging from fish to 

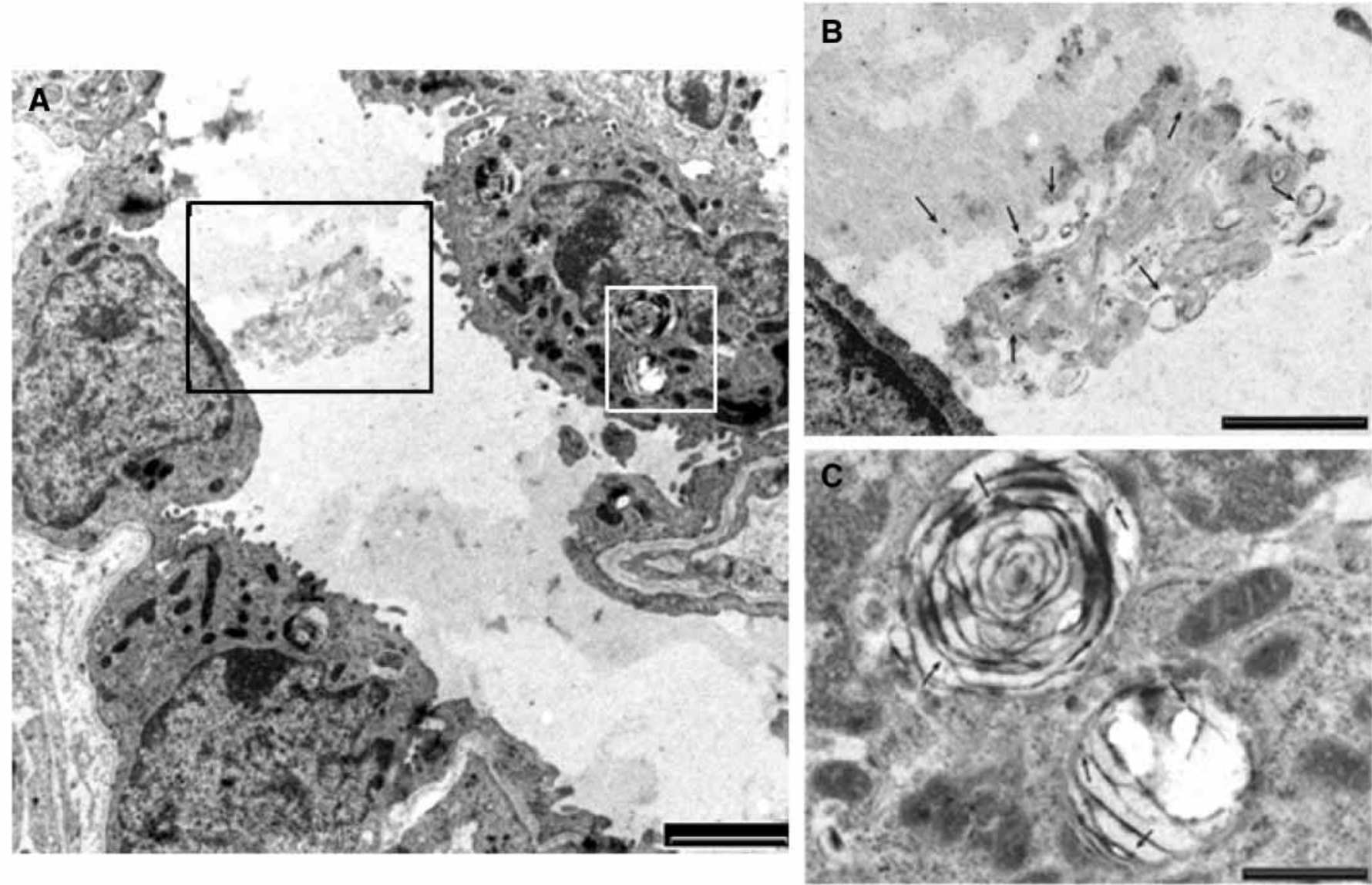

Fig. 4. (A) Low-magnification electron micrograph of lung tissue from Macropus eugenii at birth. Scale bar, $2 \mu \mathrm{m}$. (B) Enlargement of the airspace region highlighted in black in A, showing the distribution of SP-D associated with large aggregate extracellular surfactant. Immunogold particles are indicated by arrows. Scale bar, $1 \mu \mathrm{m}$. (C) Enlargement of the cell region highlighted in white in A, showing the distribution of SP-D associated with the periphery of the lamellar bodies. Immunogold particles are indicated by arrows. Scale bar, $0.5 \mu \mathrm{m}$.

amphibians and lizards (Wood et al., 2000). The cells are polar, with a large nucleus and prominent microvilli. At birth, there are numerous ATII cells lining the airspaces, which is indicative of the highly proliferative nature of the lung at this stage of development. Furthermore, at this age, the lung is still very underdeveloped, with the ATII cells not yet differentiated into type I cells. As the lung matures, the ATII cells differentiate into type I cells, reducing the number of ATII cells.

\section{Immunohistochemistry}

At birth, both SP-A and SP-B were found in the lamellar bodies and cytoplasm of the ATII cells and also in the airspaces. The processing of SP-A in mammals is still controversial. The hydrophobic proteins (SP-B and SP-C) undergo processing in the rough endoplasmic reticulum and in the Golgi apparatus before they are proteolytically processed to the mature form in the multivesicular bodies. They are then transported to the lamellar bodies and secreted into the airspace (McCormack, 1998; Voorhout et al., 1992). While some SP-A is detected in the periphery of lamellar bodies by immunohistochemistry (Williams and Benson, 1981), the amount of SP-A detected by the same methods in the airspaces and associated with tubular myelin is far greater (Haller et al., 1992). Furthermore, SP-A represents approximately $50 \%$ of total protein in lavaged surfactant and only $1 \%$ of total protein in lamellar bodies (Oosterlaken Dijksterhuis et al., 1991). This, therefore, suggests that SP-A is predominantly secreted through a pathway that bypasses the lamellar bodies (McCormack, 1998). Certainly in the wallaby, the amount of SP-A labelling in the airspaces was much greater than that in the lamellar bodies. SP-A was also found closely associated with surfactant aggregates in the newborn wallaby lung. This is not surprising because SP-A is thought to be necessary for the structural integrity of tubular myelin (a cross-hatched lattice structure characteristic of alveolar surfactant in most vertebrates). SP-A has been localised to the corners of tubular myelin (Voorhout et al., 1991b), and it is this lattice that is thought to supply the lipids to the surface-active monolayer (Goerke, 1998).

Unlike SP-A, SP-B is stored and released together with the phospholipids via the lamellar bodies (Weaver, 1998). Furthermore, SP-B may play a very important role in the formation of the lamellar bodies by maintaining membrane stabilisation by decreasing charge repulsion and/or forming 


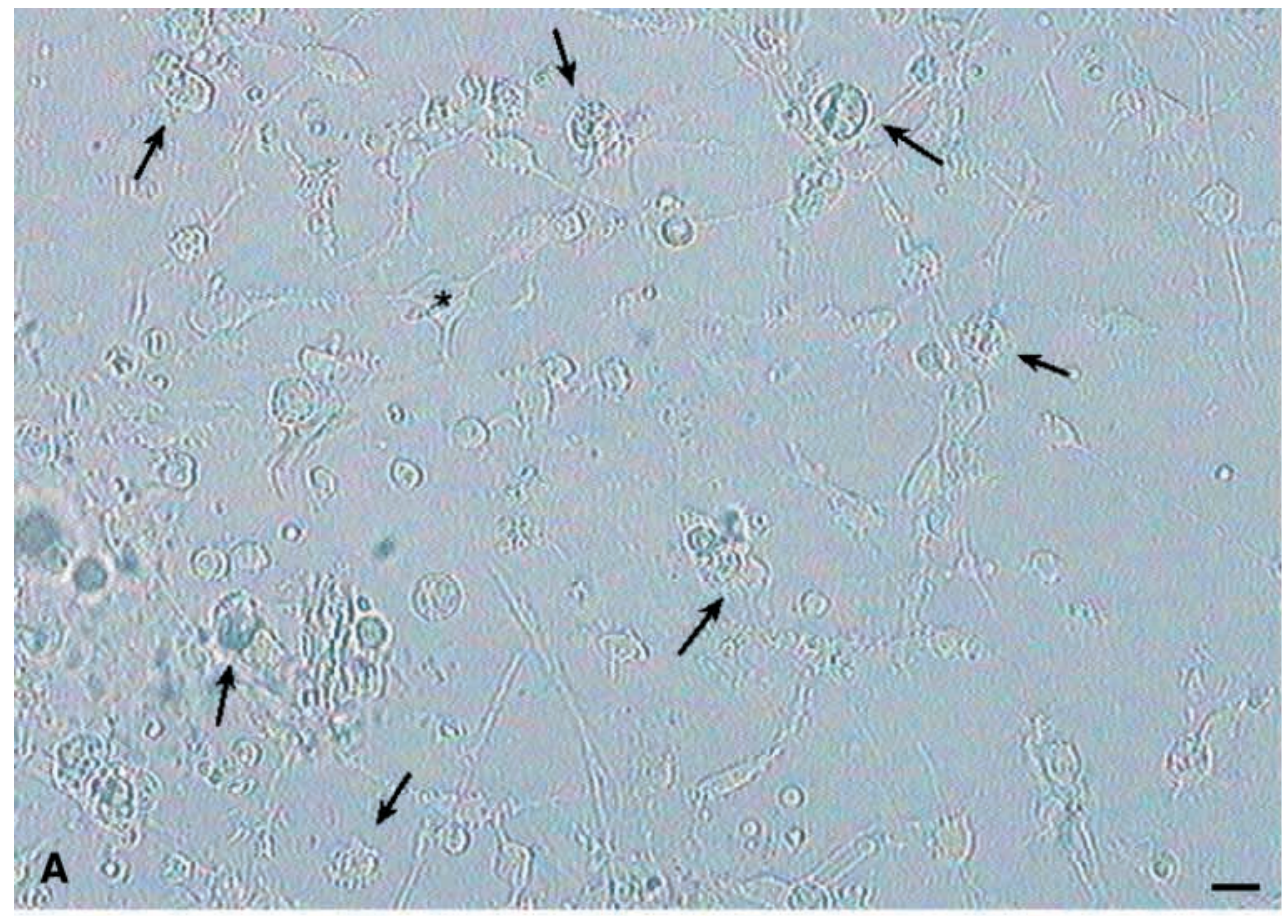

Fig. 5. (A) Type II cells (arrows) cocultured with fibroblasts (asterisk) isolated from the lung of Macropus eugenii at 70 days of age. Scale bar, $10 \mu \mathrm{m}$. (B) Fluorescence microscopy of the same culture of type II cells isolated from the lung of Macropus eugenii seen in A, showing lamellar bodies fluorescing green after incubation with LysoTracker Green DND-26. Cells were examined using an excitation filter, BP460-490, and a barrier filter, BA510IF. Scale bar, $10 \mu \mathrm{m}$.

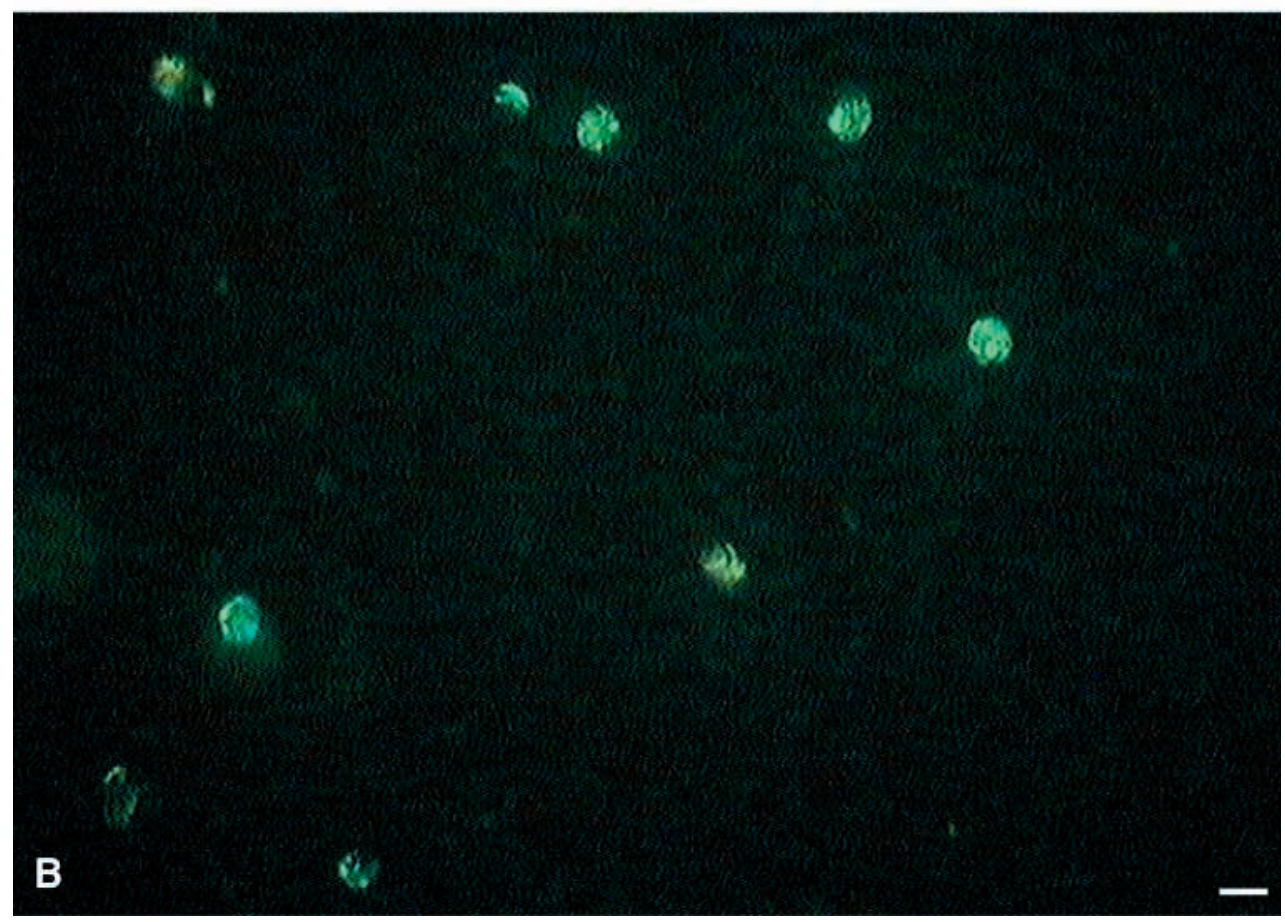

homodimers with adjacent membranes (Weaver, 1998). In the wallaby at birth and throughout development, SP-B was detected in the cytoplasm in close proximity to lamellar bodies, in the lamellar bodies themselves as well as in the airspaces. The abundance of SP-B in the airspace can be explained by its importance in the formation of tubular myelin (Johansson et al., 1994) and its ability to promote adsorption of lipids to the air/liquid interface, stabilise the monolayer and enhance the respreading of surface films after lung collapse (Hawgood et al., 1998).
SP-D was also detected in both intra- and extracellular surfactant compartments of the lung of the newborn wallaby. However, its distribution in lamellar bodies was very sparse, and it appeared to be present only along the periphery. As with SP-A, it appears that SP-D is not stored or secreted with lamellar bodies in the human lung (Johansson et al., 1994), although it is processed in the rough endoplasmic reticulum and Golgi apparatus (Crouch, 1998). However, in the wallaby, both SP-A and SP-D were detected in the lamellar bodies throughout development. Similarly, in mammals, some SP-A 


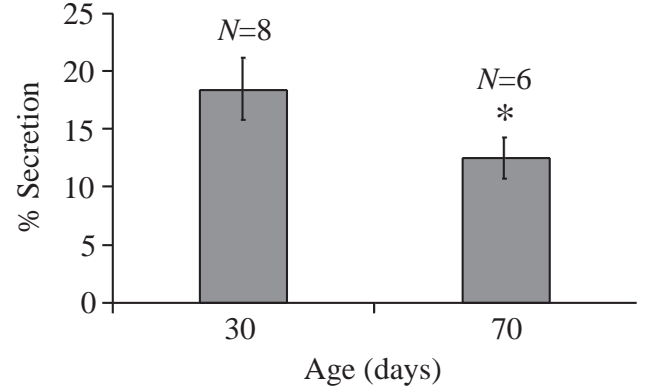

Fig. 6. The basal phosphatidylcholine secretion of alveolar type II cells from 30- and 70-day-old Macropus eugenii. An asterisk indicates a significant decrease between 30 and 70 days $(P<0.05)$. The sample size of each group is indicated above each column. Values are means \pm S.E.M.
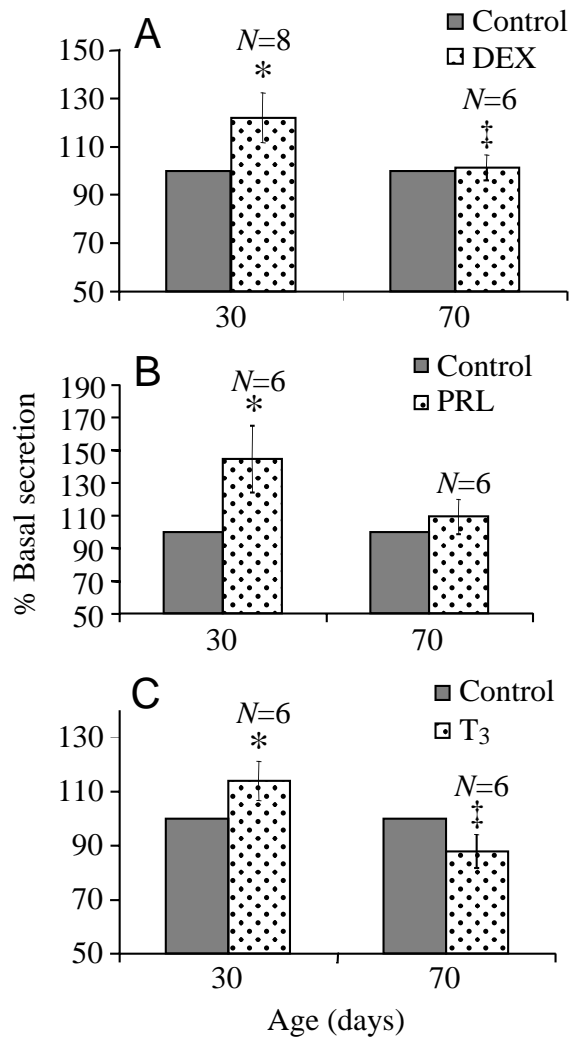

Fig. 7. The effects of the hormones dexamethasone (DEX) (A), prolactin (PRL) (B) and triiodothyronine $\left(\mathrm{T}_{3}\right)(\mathrm{C})$ on the amount of phosphatidylcholine secreted as a percentage of basal secretion from alveolar type II cells of 30- and 70-day-old Macropus eugenii. An asterisk indicates a significant increase above basal secretion $(P<0.05)$. A double dagger indicates a significant decrease in agonist-stimulated secretion between 30- and 70-day-old joeys $(P<0.05)$. The sample size of each group is indicated above each column. Values are means \pm S.E.M.

is detected in the lamellar bodies (Williams and Benson, 1981). It is unclear why this is so. Given the relative paucity of label on the lamellar bodies, compared with the airspace, it is possible that the presence in the lamellar bodies reflects a

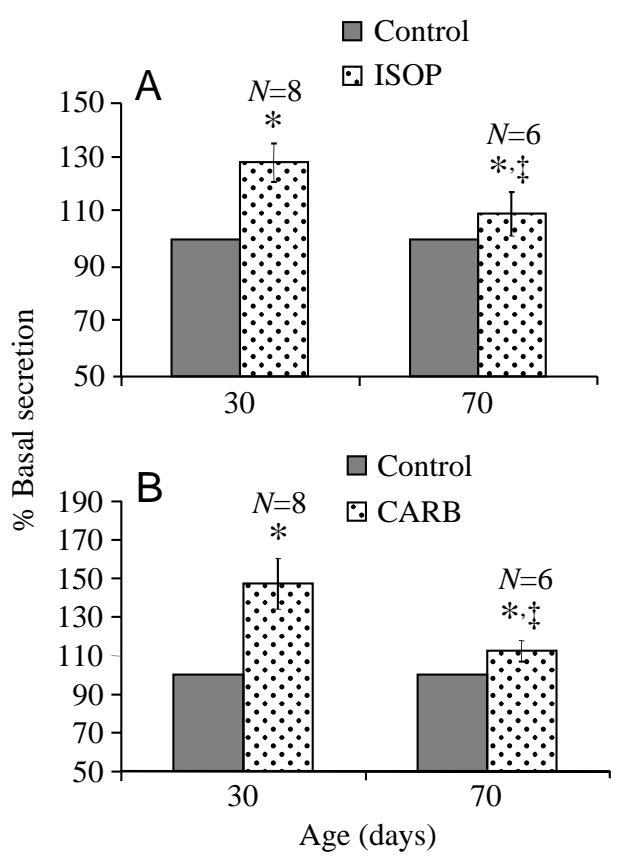

Fig. 8. The effects of the autonomic secretagogues isoproterenol (ISOP) (A) and carbamylcholine chloride (CARB) (B) on the amount of phosphatidylcholine secreted as a percentage of basal secretion from alveolar type II cells of 30- and 70-day-old Macropus eugenii. An asterisk indicates a significant increase above basal secretion $(P<0.05)$. A double dagger indicates a significant decrease in agonist-stimulated secretion between 30- and 70-day-old joeys $(P<0.05)$. The sample size of each group is indicated above each column. Values are means \pm S.E.M.

degree of non-specific binding. However, considering the amount of gold labelling found on the lamellar bodies and the amount of non-specific binding found in the negative controls, this seems unlikely. However, it is possible that in proteins associated with complex structures such as organelles there is a higher degree of antigenic masking, compared with, for example, the proteins present in the airspace. Therefore, the quantification of immunogold labelling between different compartments is difficult. The great abundance of SP-D in the airspaces of the lungs of newborn wallabies may be explained by the fact that SP-D is secreted directly into the airspace, where it functions in the host defence system to bind to pathogens (Reid, 1998) and to protect the alveolar lining from oxidative cellular damage (Bridges et al., 2000).

The presence of all three proteins in their secreted form at birth (when the lung is in the early stages of the terminal airsac phase) suggests a functional surfactant. In eutherian mammals such as the human, sheep, horse and guinea pig, the surfactant system is complete by the terminal air-sac phase (Pattle et al., 1975; Sosenko and Frank, 1987), which occurs well before birth. We therefore suggest that the development of the surfactant system is coupled with the terminal air-sac stage of lung development rather than the length of in-utero gestation or the onset of birth and, therefore, air-breathing. Hence, lung development of marsupials can be compared with 
that of eutherian mammals, despite the difference in birthing strategies and gestational age.

\section{Cell culture}

The attachment of cells to a base, i.e. basement membrane in vivo or tissue culture plate in vitro, has been shown to be important in maintaining basic cell function (Shannon et al., 1987). The cells isolated from $M$. eugenii in this experiment did not adhere to the tissue culture plates but remained as a suspended monolayer just above the base of the plate. However, these cells appear to retain their original morphology, including the presence of lamellar bodies (Fig. 5A,B), and function (e.g. their ability to secrete proteins and lipids). Secretion studies have also been performed on suspended cells from another marsupial, the fat-tailed dunnart (Ormond et al., 2001), as well as a lizard, frog and lungfish (Wood et al., 1999, 2000).

At 30 days of age, the basal secretion of PC was significantly higher than that at 70 days, suggesting that, at this early stage, the cells are extremely active and they secrete very large amounts of surfactant. This finding, therefore, supports the morphological observations, which suggest that the lung at this early stage is in a highly proliferative phase and is maturing rapidly (Runciman et al., 1996). As the cells mature, and the levels of proliferation and growth in the lung decrease, the activity of the ATII cells also decreases, resulting in a decrease in PC secretion. It is known that maturing ATII cells from human lungs begin to store more PC in lamellar bodies (Gonzales et al., 1990), resulting in a delay in PC secretion and an overall reduction in turnover. By examining rates of synthesis as well as secretion over extended incubation periods, it can be determined whether the decrease in PC secretion in the isolated ATII cells of the wallaby is a factor of the incubation period used or is due to a general reduction in turnover rate. In chicken cells, a $4 \mathrm{~h}$ incubation with agonists gave a maximal response, which reached a plateau at longer incubation times (Sullivan and Orgeig, 2001).

DEX and $\mathrm{T}_{3}$ both significantly increased PC secretion from ATII cells from 30-day-old, but not from 70-day-old, joeys. In the immature lung, DEX (and $\mathrm{T}_{3}$ to a lesser extent) causes an increase in cell activity resulting in maturation, cell differentiation and growth and an increase in PC secretion (Ballard and Ballard, 1972; Funkhouser and Hughes, 1977). At 30 days of age, the lung is still in the terminal air-sac stage and is undergoing rapid growth and maturation. The addition of either DEX or $\mathrm{T}_{3}$, therefore, caused an increase in PC secretion as a result of the increased cell activity. At 70 days of age, the lung has entered the alveolar stage of development, and both DEX and $\mathrm{T}_{3}$ failed to stimulate PC secretion. A similar result was observed in foetal chicken cells and in sea turtle cells, where DEX increased PC secretion in the early stages, but had no effect in the late-stage foetus or the hatchling (Sullivan et al., 2001; Sullivan and Orgeig, 2001). However, in both the sea turtle and the chicken, $\mathrm{T}_{3}$ caused a significant increase in PC secretion at all stages.

In mammals, there generally appears to be a relatively modest effect of glucocorticoids on adult ATII cells (Young and Silbajoris, 1986). Glucocorticoids act on ATII cells indirectly by acting on fibroblasts, which secrete a factor that acts on the ATII cells to stimulate PC secretion. As mature rat ATII cells secrete a factor that inhibits fibroblast function and, therefore, the response to glucocorticoids (Adamson et al., 1991), this may represent the mechanism by which glucocorticoids are not as effective in adult lung tissue. The ATII cells of wallabies at 70 days of age are approaching maturity, so this mechanism may explain the lack of a response to DEX at this age. Early in development, ATII cells secrete PC almost immediately after it is synthesised, but as the cells mature, more PC is stored in lamellar bodies, resulting in a delay in secretion after synthesis (Gonzales et al., 1990). The immediate secretion of PC may explain the increase in PC secretion seen after the addition of $\mathrm{T}_{3}$ to cells of 30-day-old joeys. However, the lack of a response to $\mathrm{T}_{3}$ at 70 days caused by the delay in secretion may be due to increased storage. An increase in the incubation period of the cells with the hormone may have resulted in a measurable increase in PC secretion.

PRL caused a significant increase in PC secretion from ATII cells of 30-day-old joeys, but had no effect on cells from 70day-old joeys. PRL regulates PC production by acting on receptors found on lung membranes. The concentration of PRL receptors on various tissues, e.g. liver, decreases as age increases (Barash et al., 1983). This may also be true for lung tissue, which could explain why PRL caused a visible response in the earlier age group, but did not appear to affect PC secretion in the later age group. Labbe et al. (1992) demonstrated that prolactin does not bind to adult human or adult rabbit lung. Since the wallaby lung at 70 days of age is in the alveolar stage, where mature alveoli are forming and the lung is beginning to appear more like the adult form, a reduced response to PRL is not unexpected.

ISOP caused a significant increase in PC secretion at both 30 and 70 days of age. ISOP increases PC secretion in other vertebrates such as reptiles, birds and mammals (Sullivan and Orgeig, 2001; Wood et al., 1999). The adrenergic pathway is also a major stimulus for PC secretion in M. eugenii in both immature (30 days) and almost mature (70 days) cells. As adrenaline is one of the universal stimulating factors, which is secreted in response to external stimuli such as temperature or stresses, it functions in both developing and mature animals. However, the response to ISOP did decrease with advancing age. It is possible that the reduced basal activity of the cells results in a slower turnover of PC. A longer incubation time might have restored the response to adrenaline.

CARB caused a significant increase in PC secretion from cells at both 30 and 70 days of age. Cholinergic agonists are able to stimulate PC secretion in lizards (Wood et al., 1999), lungfish, frogs and dunnarts (Wood et al., 2000) by acting through muscarinic receptors on the ATII cells. However, cholinergic agonists have no effect on PC secretion from isolated ATII cells of eutherian mammals (Brown and Longmore, 1981; Dobbs and Mason, 1979; Oyarzun and Clements, 1977). The cholinergic pathway may be present in heterothermic animals as a 
mechanism to maintain secretion during periods of cold (Wood et al., 2000). At the ages examined, the joeys are ectothermic and, therefore, respond more like reptiles or heterothermic mammals than endothermic mammals. This may explain why CARB was able to stimulate PC secretion at these ages.

With all the agonists, both hormones and autonomic secretagogues, there was a significant difference in percentage basal secretion between 30 and 70 days of age. As this measure takes into account the reduced basal secretion at 70 days, it appears that there is an additional effect acting to reduce secretion further. The reduction in the percentage basal secretion of $\mathrm{PC}$ at 70 days may be due to a decrease in the sensitivity of the cells to the agonists. There are two mechanisms that might bring about this reduction: either a reduction in the ability of the hormone to react with the receptors or a decrease in the number of receptors. The latter appears to be the more likely, since preliminary evidence from this study indicates that increasing the concentration of the agonists does not alter the effect on PC secretion.

\section{Concluding remarks}

This study demonstrates that three of the four surfactant proteins, SP-A, SP-B and SP-D, are present in the lung of $M$. eugenii at birth, when the lung is in the early stages of the terminal air-sac phase. Hence, most mammals appear to have a functional surfactant system when the lungs enter the terminal air-sac phase. This is independent of birth or birthing strategy, length of gestation or the onset of air-breathing, but appears to be coupled with lung development. In the future, quantitative analyses should be conducted on the surfactant proteins to establish whether there is a further maturation process that occurs or whether protein levels are set at birth. Possibly, the proteins may alter their turnover rates in a manner similar to that of PC. PC secretion in alveolar type II cells of the wallaby is controlled by both hormones and autonomic secretagogues during the early stages of development but, as the lung matures, hormones lose their effect and autonomic secretagogues elicit a reduced response. Future studies should establish the pathways through which both the hormones and the autonomic secretagogues cause the increase in PC secretion and determine whether the pathways themselves are affected as the lungs mature. As the stimuli for surfactant development are similar to those of eutherian mammals, marsupials may represent useful alternative animal models for the investigation of surfactant development. Marsupials are well suited to developmental studies because the developing foetus is easily accessible and can be manipulated readily.

The authors wish to thank Jayne Skinner, Dr Glenn Shimmin, Jonathan Codd and Simon Chamberlain for their assistance in animal handling, Dr Marilyn Henderson and Lyn Waterhouse at the Centre for Electron Microscopy and Microanalysis (CEMMSA) for their training and assistance in electron microscopy techniques, the OLYMPUS Imaging Unit for use of the fluorescence microscope and the Parasite Systematics and Diagnostics Program who provided the expertise to use the equipment. We also thank Lucy Sullivan for training and assistance in cell culture techniques and Dr Philip Wood for surgical assistance. This work was funded by an Australian Research Council (ARC) grant to C.B.D. and an ARC Research Fellowship to S.O. All animal surgery was performed under a permit from the University of Adelaide Animal Ethics Committee (permit number S/10/00).

\section{References}

Adamson, I. Y., Young, L. and King, G. M. (1991). Reciprocal epithelial:fibroblast interactions in the control of fetal and adult rat lung cells in culture. Exp. Lung Res. 17, 821-835.

Ballard, P. L. and Ballard, R. A. (1972). Glucocorticoid receptors and the role of glucocorticoids in fetal lung development. Proc. Natl. Acad. Sci. USA 69, 2668-2672.

Ballard, P. L., Hovey, M. L. and Gonzales, L. K. (1984). Thyroid hormone stimulation of phosphatidylcholine synthesis in cultured fetal rabbit lung. $J$. Clin. Invest. 74, 898-905.

Barash, I., Madar, Z. and Gertler, A. (1983). Down-regulation of prolactin receptors in the liver, mammary gland and kidney of female virgin rat, infused with ovine prolactin or human growth hormone. Biochem. Biophys. Res. Commun. 116, 644-650.

Bligh, E. G. and Dyer, W. J. (1959). A rapid method of total lipid extraction and purification. Can. J. Biochem. 37, 911-917.

Bridges, J. P., Davis, H. W., Damodarasamy, M., Kuroki, Y., Howles, G., Hui, D. Y. and McCormack, F. X. (2000). Pulmonary surfactant proteins $\mathrm{A}$ and $\mathrm{D}$ are potent endogenous inhibitors of lipid peroxidation and oxidative cellular injury. J. Biol. Chem. 275, 38848-38855.

Brown, L. S. and Longmore, W. J. (1981). Adrenergic and cholinergic regulation of lung surfactant secretion in the isolated perfused rat lung and in the alveolar type II cell in culture. J. Biol. Chem. 256, 66-72.

Burri, P. H. (1984). Fetal and postnatal development of the lung. Annu. Rev. Physiol. 46, 617-628.

Crouch, E. C. (1998). Structure, biologic properties and expression of surfactant protein D (SP-D). Biochim. Biophys. Acta 1408, 278-289.

Curstedt, T., Jornvall, H., Robertson, B., Bergman, T. and Berggren, P. (1987). Two hydrophobic low-molecular mass protein fractions of pulmonary surfactant: characterization and biophysical activity. Eur. J. Biochem. 168, 255-262.

Dobbs, L. G. and Mason, R. J. (1979). Pulmonary alveolar type II cells isolated from rats. J. Clin. Invest. 63, 378-387.

Frappell, P. B. and Mortola, J. P. (2000). Respiratory function in a newborn marsupial with skin gas exchange. Respir. Physiol. 120, 35-45.

Funkhouser, J. D. and Hughes, E. R. (1977). Glucocorticoids and fetal lung development. J. Steroid Biochem. Mol. Biol. 8, 519-524.

Gemmell, R. T. (1986). Lung development in the marsupial bandicoot, Isoodon macrourus. J. Anat. 148, 193-204.

Goerke, J. (1998). Pulmonary surfactant: Functions and molecular compositon. Biochim. Biophys. Acta 1408, 79-89.

Gonzales, L. W., Ertsey, R., Ballard, P. L., Froh, D., Goerke, J. and Gonzales, J. (1990). Glucocorticoid stimulation of fatty acid synthesis in explants of human fetal lung. Biochim. Biophys. Acta 1042, 1-12.

Gregory, T. J., Longmore, W. J., Moxley, M. A., Whitsett, J. A., Reed, C. R., Fowler, A. A., Hudson, L. D., Maunder, R. J., Crim, C. and Hyers, T. M. (1991). Surfactant chemical composition and biophysical activity in acute respiratory distress syndrome. J. Clin. Invest. 88, 1976-1981.

Haagsman, H. P. (1998). Interactions of surfactant protein A with pathogens. Biochim. Biophys. Acta 1408, 264-277.

Haagsman, H. P. and Van Golde, L. M. G. (1991). Synthesis and assembly of lung surfactant. Annu. Rev. Physiol. 53, 441-464.

Haller, E. M., Shelley, S. A., Montgomery, M. R. and Balis, J. U. (1992). Immunocytochemical localization of lysozyme and surfactant protein A in rat type II cells and extracellular surfactant forms. J. Histochem. Cytochem. 40, 1491-1500.

Hamosh, M. and Hamosh, P. (1977). The effect of prolactin on the lecithin content of fetal rabbit lung. J. Clin. Invest. 59, 1002-1005.

Hawgood, S., Derrick, M. and Poulain, F. (1998). Structure and properties of surfactant protein B. Biochim. Biophys. Acta 1408, 150-160.

Hayat, M. A. (1970). Principles and Techniques of Electron Microscopy. New York: Van Nostrand Reinhold Company. 
Hinds, L. A. and Loudon, A. S. I. (1997). Mechanisms of seasonality in marsupials: A comparative view. In Marsupial Biology: Recent Research, New Perspectives (ed. N. J. Saunders and L. A. Hinds), pp. 41-70. Sydney: UNSW Press Ltd.

Janssens, P. A., Grigg, J. A., Dove, H. and Hulbert, A. J. (1990). Thyroid hormones during development of a marsupial, the tammar wallaby, Macropus eugenii. J. Endocrinol. 127, 427-436.

Johansson, J. J., Curstedt, T. and Robertson, B. (1994). The proteins of the surfactant system. Eur. Respir. J. 7, 372-391.

Johnson, M. H. and Everitt, B. J. (1995). Essential Reproduction. Oxford: Blackwell Science Ltd.

Kellendonk, C., Tronche, F., Reichardt, H. M. and Schutz, G. (1999) Mutagenesis of the glucocorticoid receptor in mice. J. Steroid Biochem. Mol. Biol. 69, 253-259.

Kresch, M. J. and Gross, I. (1987). The biochemistry of fetal lung development. Clin. Perinatol. 14, 481-507.

Labbe, A., Delcros, B., Dechelotte, P., Nouailles, C. and Grizard, G. (1992). Comparative study of the binding of prolactin and growth hormone by rabbit and human lung cell membrane fractions. Biol. Neonate 61, 179-187.

Massaro, D., Clerch, L. and Massaro, G. D. (1982). Surfactant secretion: evidence that cholinergic stimulation of secretion is indirect. Am. J. Physiol. 243, C39-C45

McCormack, F. X. (1998). Structure, processing and properties of surfactant protein A. Biochim. Biophys. Acta 1408, 109-131.

Mettler, N. R., Gray, M. E., Schuffman, S. and Lequire, V. S. (1981). Betaadrenergic induced synthesis and secretion of phosphatidylcholine by isolated pulmonary alveolar type II cells. Lab. Invest. 45, 575-586.

Miles, P. R., Wright, J. R., Bowman, L. and Castranova, V. (1983) Incorporation of $\left[{ }^{3} \mathrm{H}\right]$ palmitate into disaturated phosphatidylcholines in alveolar type II cells isolated by centrifugal elutriation. Biochim. Biophys. Acta 753, 107-118.

Mortola, J. P., Frappell, P. B. and Woolley, P. A. (1999). Breathing through skin in a newborn mammal. Nature 397, 660.

Murphy, C. R. and Smith, J. R. (1970). Age determination of pouch young and juvenile Kangaroo Island Wallabies. Trans. R. Soc. S. Aust. 94, 15-20.

Oosterlaken Dijksterhuis, M. A., van Eijk, M., van Buel, B. L., van Golde, L. M. and Haagsman, H. P. (1991). Surfactant protein composition of lamellar bodies isolated from rat lung. Biochem. J. 274, 115-119.

Ormond, C. J., Daniels, C. B. and Orgeig, S. (2001). Neurochemical and thermal control of surfactant secretion by alveolar type II cells isolated from the marsupial, Sminthopsis crassicaudata. J. Comp. Physiol. B 171, 223-230.

Oyarzun, M. J. and Clements, J. A. (1977). Ventilatory and cholinergic control of pulmonary surfactant in the rabbit. J. Appl. Physiol. 43, 39-45.

Pattle, R. E., Rossdale, P. D., Schock, C. and Creasey, J. M. (1975). The development of the lung and its surfactant in the foal and in other species J. Reprod. Fertil. (Suppl.) 23, 651-657.

Perelman, R. H., Farrell, P. M., Engle, M. J. and Kemnitz, J. W. (1985) Developmental aspects of lung lipids. Annu. Rev. Physiol. 47, 803-822.

Post, M. and Smith, B. T. (1992). Hormonal control of surfactant metabolism. In Pulmonary Surfactant: From Molecular Biology to Clinical Practice (ed. B. Robertson, L. M. G. Van Golde and J. J. Batenburg), pp. 379-424. Amsterdam: Elsevier Science Publishers B.V.

Post, M. and van Golde, L. M. (1988). Metabolic and developmental aspects of the pulmonary surfactant system. Biochim. Biophys. Acta 947, 249-286.

Reid, K. B. M. (1998). Interactions of surfactant protein D with pathogens, allergens and phagocytes. Biochim. Biophys. Acta 1408, 290-295.

Ribbons, K. A., Baudinette, R. V. and McMurchie, E. J. (1989). The development of pulmonary surfactant lipids in a neonatal marsupial and the rat. Respir. Physiol. 75, 1-10.
Robinson, P. C., Voelker, D. R. and Mason, R. J. (1984). Isolation and culture of human alveolar type II epithelial cells. Characterization of their phospholipid secretion. Am. Rev. Respir. Disease 130, 1156-1160.

Runciman, S. I., Baudinette, R. V. and Gannon, B. J. (1996). Postnatal development of the lung parenchyma in a marsupial: the tammar wallaby. Anat. Rec. 244, 193-206.

Runciman, S. I. C., Baudinette, R. V., Gannon, B. J. and Lipsett, J. (1999). Morphometric analysis of postnatal lung development in a marsupial: Transmission electron microscopy. Respir. Physiol. 118, 61-75.

Shannon, J. M., Mason, R. J. and Jennings, S. D. (1987). Functional differentiation of alveolar type II epithelial cells in vitro: effects of cell shape, cell-matrix interactions and cell-cell interactions. Biochim. Biophys. Acta 931, 143-156.

Sosenko, I. R. and Frank, L. (1987). Lung development in the fetal guinea pig: Surfactant, morphology and premature viability. Pediatr. Res. 21 , 427-431

Sullivan, L. C., Daniels, C. B., Phillips, I. D., Orgeig, S. and Whitsett, J. A. (1998). Conservation of surfactant protein A: evidence for a single origin for vertebrate pulmonary surfactant. J. Mol. Evol. 46, 131-138.

Sullivan, L. C. and Orgeig, S. (2001). Dexamethasone and epinephrine stimulate surfactant secretion in type II cells of embryonic chickens. Am. J Physiol. 281, R770-R777.

Sullivan, L. C., Orgeig, S., Wood, P. G. and Daniels, C. B. (2001). The ontogeny of pulmonary surfactant secretion in the embryonic green sea turtle (Chelonia mydas). Physiol. Biochem. Zool. 74, 493-501.

Van Petten, G. R. and Bridges, R. (1979). The effects of prolactin on pulmonary maturation in the fetal rabbit. Am. J. Obstet. Gynecol. 134 711-714.

Voorhout, V., van Genderen, I., van Meer, G. and Geuze, H. (1991a). Preservation and immunogold localization of lipids by freeze-substitution and low temperature embedding. Scan. Microsc. (Suppl.) 5, S17-S25.

Voorhout, W. F., Veenendaal, T., Haagsman, H. P., Verkleij, A. J., Van Golde, L. M. G. and Geuze, H. J. (1991b). Surfactant protein A is localized at the corners of the pulmonary tubular myelin lattice. J. Histochem. Cytochem. 39, 1331-1336.

Voorhout, W. F., Veenendaal, T., Haagsman, H. P., Weaver, T. E., Whitsett, J. A., Van Golde, L. M. G. and Geuze, H. J. (1992) Intracellular processing of pulmonary surfactant protein $\mathrm{B}$ in an endosomal/lysosomal compartment. Am. J. Physiol. 263, L479-L486.

Weaver, T. E. (1998). Synthesis, processsing and secretion of surfactant proteins B and C. Biochim. Biophys. Acta 1408, 173-179.

Whitsett, J. A. and Baatz, J. E. (1992). Hydrophobic surfactant proteins SPB and SP-C: Molecular biology, structure and function. In Pulmonary Surfactant: From Molecular Biology to Clinical Practice (ed. B. Robertson L. M. G. Van Golde and J. J. Batenburg), pp. 55-75. Amsterdam: Elsevier Science Publishers B.V.

Williams, M. C. and Benson, B. J. (1981). Immunocytochemical localization and identification of the major surfactant protein in adult rat lung. $J$ Histochem. Cytochem. 29, 291-305.

Wood, P. G., Andrew, L. K., Daniels, C. B., Orgeig, S. and Roberts, C. T. (1997). Autonomic control of the pulmonary surfactant system and lung compliance in the lizard. Physiol. Zool. 70, 444-455.

Wood, P. G., Lopatko, O. V., Orgeig, S., Codd, J. R. and Daniels, C. B. (1999). Control of pulmonary surfactant secretion from type II pneumocytes isolated from the lizard, Pogona vitticeps. Am. J. Physiol. 277, R1705-R1711.

Wood, P. G., Lopatko, O. V., Orgeig, S., Joss, J. M., Smits, A. W. and Daniels, C. B. (2000). Control of pulmonary surfactant secretion: An evolutionary perspective. Am. J. Physiol. 278, R611-R619.

Young, S. L. and Silbajoris, R. (1986). Dexamethasone increases adult rat lung surfactant lipids. J. Appl. Physiol. 60, 1665-1672. 